University of Nebraska - Lincoln

DigitalCommons@University of Nebraska - Lincoln

\title{
Phenological synchrony affects interaction strength of an exotic weevil with Platte thistle, a native host plant
}

\author{
F. Leland Russell \\ University of Nebraska-Lincoln, leland.russell@wichita.edu \\ Svata M. Louda \\ University of Nebraska - Lincoln, slouda1@unl.edu
}

Follow this and additional works at: https://digitalcommons.unl.edu/bioscilouda

Part of the Ecology and Evolutionary Biology Commons

Russell, F. Leland and Louda, Svata M., "Phenological synchrony affects interaction strength of an exotic weevil with Platte thistle, a native host plant" (2004). Svata M. Louda Publications. 20.

https://digitalcommons.unl.edu/bioscilouda/20

This Article is brought to you for free and open access by the Papers in the Biological Sciences at DigitalCommons@University of Nebraska - Lincoln. It has been accepted for inclusion in Svata M. Louda Publications by an authorized administrator of DigitalCommons@University of Nebraska - Lincoln. 
Published in Oecologia 139 (2004), pp. 525-534; doi: 10.1007/s00442-004-1543-1

Copyright (C 2004 Springer-Verlag. Used by permission.

Submitted December 16, 2003; accepted March 1, 2004; published online April 1, 2004.

PLANT ANIMAL INTERACTIONS

\title{
Phenological synchrony affects interaction strength of an exotic weevil with Platte thistle, a native host plant
}

\author{
F. Leland Russell and Svata M. Louda \\ School of Biological Sciences, University of Nebraska-Lincoln, Lincoln, NE 68588-0118, USA \\ Corresponding author - F. Leland Russell, email frussell@unlnotes.unl.edu
}

\begin{abstract}
Phenological synchrony of a consumer population with its resource populations is expected to affect interaction intensity. We quantified phenological variation and synchrony of populations of an invasive Eurasian flower head weevil, Rhinocyllus conicus, that consumes florets, ovules, and seeds of developing flower heads of a native North American thistle, Cirsium canescens, in Sand Hills prairie in Nebraska, USA. Variation in timing of adult activity among weevil populations was larger than variation in timing of flower head development among C. canescens populations, and it drove the observed variation in the phenological synchrony between weevil and host plant populations. Furthermore, the degree of phenological synchrony between populations was significant in explaining variation in weevil egg load on the newly acquired host plant. Because population growth of $C$. canescens is limited by predispersal seed losses to floral herbivores, variation in the synchrony of herbivore and plant flowering will affect the density of the plant population. These results provide strong quantitative support for the hypothesis that the synchrony of insect activity with plant resources can determine the magnitude of impact of floral herbivores on their host plant populations.
\end{abstract}

Keywords: floral herbivory, invasive species, biocontrol, predispersal seed predation, plant population dynamics

\section{Introduction}

Temporal and spatial variation in the seasonal phenology of insects and their host plants represent important parameters in the ecology and evolution of herbivore-plant interactions (Augspurger 1981; Hunter 1992; Stenseth and Mysterud 2002). Masting, the betweenyear variation in seed resource availability, and its consequences for consumer-plant interactions has been examined intensively (Elkinton et al. 1996; Herrera et al. 1998; Schnurr et al. 2002). However, the number of stud- ies that have examined the consequences of temporal and spatial variation in within-season phenological synchrony, the relative timing of consumer and resource populations (Rathcke and Lacey 1985), for populations of the resource species is much smaller.

Studies of within-season phenological synchrony have focused on two main issues. For plants, the main issue has been how seasonal variation in timing of the interacting species affects the level of herbivory on individual plants and individual plant fitness. These studies typically examine variation among individuals in: (1) flowering or leaf expansion (Mopper and Simberloff 1995; Pilson 2000), (2) flowering synchrony with others in the population (Augspurger 1981; Ollerton and Lack 1998), or (3) flowering strategy, i.e., synchronous versus gradual flower presentation (Eriksson 1995) (Table 1: questions 1-3). We found no studies that addressed the consequences of variation in the relative timing of insects and their host plants for host plant populations. For insects, the focus has been on effects of seasonal variation in the phenological synchrony of insects and plants on insect population dynamics (Table 1: questions 5 and 6). These studies often address the relationship between individual plant phenology and insect abundance on the plant (Crawley and Akhteruzzaman 1988; Hunter 1992; Hodkinson et al. 2001), or the role of insect-plant synchrony in insect outbreaks (Kerslake and Hartley 1997; Hunter and Elkinton 2000).

Unexpectedly, in a voluminous literature on the seasonal phenology of insect-plant interactions, we found only 18 studies that quantified the within-season synchrony of populations of both a consumer and its resource (Table 2). More studies of the effects of phenological mismatches on consumer and resource population dynamics are needed (Stenseth and Mysterud 2002), es- 
Table 1. Questions generally asked about the ecological and evolutionary effects of seasonal phenology of interacting phytophagous insects and host plants (1993-2002), with example studies. Phenology is defined as seasonal timing within year (Rathcke and Lacey 1985), so excludes masting.

No. Question (related studies)

1 Does herbivory affect leaf or reproductive phenology of an individual plant in future growing seasons? (Kaitaniemi et al. 1997; Quiring and McKinnon 1999)

2 Does individual plant phenology affect the amount of herbivore damage to it? (Angulo-Sandoval and Aide 2000; Mopper and Simberloff 1995)

3 Do herbivores affect evolution of individual plant leaf or reproductive phenology? (Ollerton and Lack 1998; Pilson 2000)

$4 \quad$ Does plant species phenology determine host species use by insects? (Hodkinson 1997; Tikkanen et al. 1999)

5 Does year-to-year variation in the synchrony of insect and plant populations affect insect population size, especially outbreaks? (Hunter and Elkinton 2000; Kerslake and Hartley 1997)

6 Does variation in plant phenology explain spatial structure of phytophagous insect abundances, such as among individual plants? (Hodkinson et al. 2001; Rodriguez et al. 1994)

7 Does host plant phenology explain seasonal variation in herbivorous insect abundance? (Alonso and Herrera 2000) or migratory patterns (Peterson 1997)

8 Does insect phenology relative to plant phenology determine response to novel plant tissue quality? (Martel et al. 2001).

pecially because climate change may differentially affect the phenologies of species at different trophic levels (Buse and Good 1996; Inouye et al. 2000; Visser and Holleman 2001). Furthermore, among these 18 studies, we found that measures of phenological synchrony of insect and plant populations were inconsistent. Yet, we found no evaluation or discussion of the relative merits of the most commonly used measures of phenological synchrony between populations.

In this study, we evaluated the degree of within-season phenological synchrony between populations of an invasive biocontrol weevil, Rhinocyllus conicus, a Eurasian thistle flower head feeder, and the floral resources presented by populations of a newly adopted, native North American host plant, Platte thistle (Cirsium canescens Nutt.). Synchrony between flower head development by $C$. canescens and oviposition activity of $R$. conicus adults was hypothesized to explain the extent of $R$. conicus herbivory on this host species in the Sand Hills midgrass prairie of the central Great Plains (Louda 1998). We used a long-term (12 year) data set on Platte thistle flowering, augmented by 4 years of intensive measurement of weevil activity patterns, to ask specifically: Does variation in the phenological synchrony of $R$. conicus and floral resources of $C$. canescens explain variation in $R$. conicus oviposition and damage among $C$. canescens populations, within or among years? We also examined the role of key climatic variables in explaining temporal and spatial variation in reproductive phenology of $C$. canescens populations. Finally, we reviewed the strengths and constraints of the various measures used to quantify the seasonal synchrony of consumer and resource populations.

\section{Materials and methods}

Sites and natural history

Field data were collected at eight sites in two mid-grass prairie preserves owned by The Nature Conservancy in the Nebraska
Sand Hills, in the upper Great Plains USA. The two preserves were: Arapaho Prairie Preserve (Arthur County) in the southwest and Niobrara Valley Preserve (Brown County) in the north-central Sand Hills, $270 \mathrm{~km}$ from Arapaho Prairie.

The flower head weevil, Rhinocyllus conicus, is native to Europe and was introduced deliberately into North America in 1969 against weedy exotic thistles, especially musk (nodding) thistle, Carduus nutans L. (Zwölfer and Harris 1984). The weevil invaded the two Sand Hills preserves in 1992-1993, far from the tallgrass habitat where musk thistle occurs (Louda et al. 1997; Louda 1998). Weevils oviposit on thistle flower heads that have not yet exerted florets. Eggs are laid under externally obvious egg cases made of masticated plant tissues. Larvae develop in the flower heads, consuming receptacle tissues, florets, ovules and seeds of the developing inflorescences. Development takes 53-76 days, allowing one generation per year (Zwölfer and Harris 1984).

Platte thistle (Cirsium canescens Nutt.) is restricted to the northcentral Great Plains, occurring in prairies on sand and gravel soils; the center of its distribution is the Nebraska Sand Hills (Great Plains Flora Association 1986). Platte thistle is a tap-rooted, relatively short-lived, monocarpic perennial. The earliest flower heads are initiated in early May and flower in late May to mid-June. Flower head development is determinant, and flower head position is a good index of relative flower head timing of development. Flower head development and seed maturation are completed by the end of June. Densities in Platte thistle populations are limited by seed input (Louda and Potvin 1995b). Therefore, additional ovule and seed consumption by $R$. conicus larvae is likely reducing densities of C. canescens populations further (Louda and Arnett 2000).

\section{Data collection}

Flowering and floral herbivory by all insects on C. canescens were quantified by sampling adult plants at each preserve 1990-2001. In 1997-2000 we added intensive, twice weekly measurements of insect numbers on plants in at least two sites per preserve (Niobrara: inner and outer Salzman 1997-2000, and Mahoney 1998-2000; Arapaho: at least two of the following, JBO, RBO, West Foothills or Wilson, depending on the availability of flowering plants). At each site in each year (1990-2001), we marked every bolting C. canescens plant located along walking transects in late May $(12 \geq n \geq$ 5). Lower sample sizes in some sites and years reflect low densities of bolting $C$. canescens. Platte thistle is a relatively sparse plant species; on average, densities of bolting Platte thistles are $<0.1$ plant/ha across the Sand Hills (Louda, unpublished data) 
Table 2. Studies that quantify magnitude and variation in seasonal phenological synchrony of field populations of consumer and resource species. Pollination studies are included because pollinators often consume nectar or pollen. Measures of seasonal phenological synchrony were: (1) "time difference" = calendar days elapsed between first (or median) appearance or modal abundance of consumer and resource; ( 2) "thermal difference" = difference in thermal units accumulated between first (or median) appearance or modal abundance of consumer and resource; and, (3) "proportion appeared" = difference between proportion of consumer population present and proportion of resource population available on a fixed date. For both time difference and thermal difference, three basic distribution parameters have been used: first appearance, median appearance, modal abundance; these are indicated parenthetically.

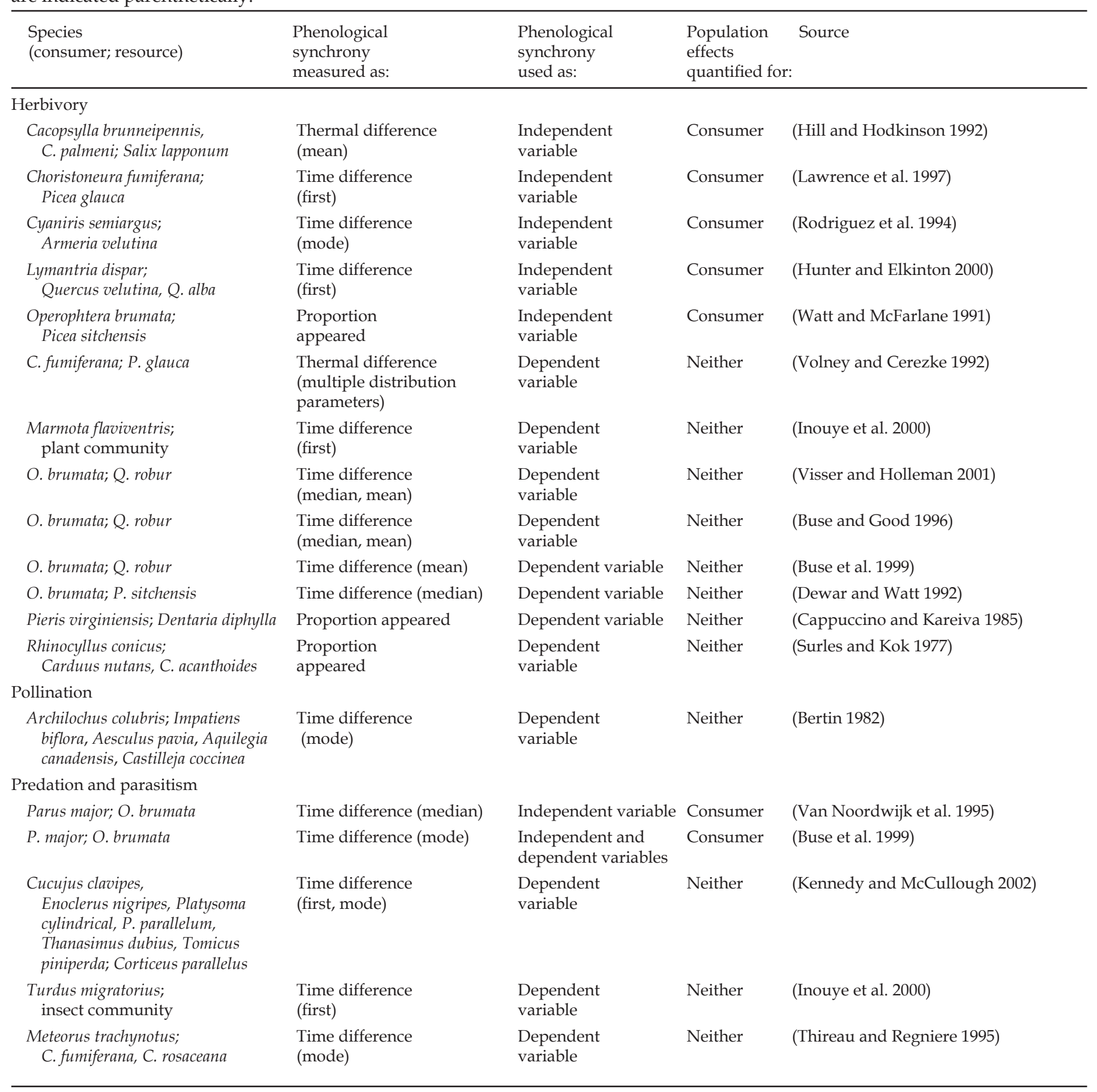

Flowering plants develop rapidly in May and mature seed in June; we measured plant development and all flower heads on each plant three (or four) times during this flowering period: (1) very early (early May) in most years, at the beginning of flower head initiation; (2) early-mid season (late May), when R. conicus adult activity and $C$. canescens flower head initiation were at peak levels; and (3) mid-late season (late June), when R. conicus had finished oviposition and C. canescens had finished maturing most of 
its seed. We verified that we had not missed any later plant flower development by sampling again (4) late season (mid-late July), when no adult $R$. conicus remained and any late flower heads had matured. On each date, plant height, flower head development, and size (diameter, $\mathrm{mm}$ ) of all heads were recorded. Development categories for individual flower heads were; " 1 " no florets exerted and diameter < $15 \mathrm{~mm}$, "2" no florets and diameter $\geq 15 \mathrm{~mm}$, "3" $>1$ floret exerted, " 4 " full flowering, and " 5 " post-flowering (following Lamp 1980).

We counted all insects present, including $R$. conicus egg cases per head after invasion, on each sampling date 1990-2001. For 1997-2000, to better quantify within-season phenology of R. conicus abundance and oviposition, we also counted insects at 4-day intervals (range 3-5 days) May-July, and noted the number of flower heads available.

Daily temperature and precipitation data for 1990-2001 were obtained from automated weather network stations at Arapaho and Ainsworth Nebraska, $20 \mathrm{~km}$ south of Niobrara.

\section{Statistical analyses}

\section{Weevil oviposition}

We used Kruskal-Wallis tests (Sokal and Rohlf 1995) to compare $R$. conicus oviposition on $C$. canescens among years for each preserve, and a Wilcoxon ranked sum test to compare oviposition between preserves. Oviposition use by $R$. conicus was quantified for each plant as the mean number of egg cases per flower head initiated for each plant. We divided the number of egg cases on individual plants by the number of heads initiated by the plant to take into account that larger plants could have more egg cases because they produced more flower heads.

\section{Phenology and synchrony}

To quantify weevil phenology for preserves and sites, we calculated the proportion of the total cumulative number of weevils observed during a growing season that were seen by late May when oviposition activity was highest. The cumulative number of weevils observed at a site or preserve during a growing season was the sum of the weevil counts made at 4-day intervals (1997-2000). If weevils were observed on our first visit, we corrected the cumulative total by using the rate of increase in weevil numbers for the years when measurements started before weevils appeared. To quantify flower head development phenology of C. canescens plants for preserves and sites, we calculated the proportion of the total number of flower heads produced per plant over the season (1990-2001) that were initiated by late May when flower head development was peaking. We quantified the degree to which $R$. con$i$ icus phenology was ahead of C. canescens phenology as the proportion of adult weevils observed minus the mean proportion of $C$. canescens flower heads initiated by late May. We refer to this difference as the "degree R. conicus preceded C. canescens." This measure was positive when $R$. conicus was earlier than $C$. canescens, and negative when $R$. conicus was later than $C$. canescens. The absolute value of this measure indicates the magnitude of the asynchrony of $R$. conicus and $C$. canescens populations. Larger absolute values indicate greater asynchrony than smaller absolute values.

We quantified phenologies of $R$. conicus and C. canescens populations in late May because our previous data indicated that, on average, both weevil activity and plant floral development were peaking at this time (Louda 1998, 1999). We used the late May sampling date as the criterion for investigation of relative phenologies based on the biology of the interaction; this was the time during which we could identify maximum differences in weevil activity and flower head initiation. The data from June and July were required to tally cumulative total number of eggs laid and cumulative flower heads produced, but were not informative on variation in the development of the interaction.

We used a two-way ANOVA to test for significant variation in C. canescens phenology among preserves and years, using Fischer's LSD to evaluate differences. Proportions were arcsine-transformed. We used a $2 \times 4 \times 2$ contingency table analysis to determine whether the number of adult weevils observed by late May varied significantly among preserves and years, controlling for among preserve and year differences in the total number of adult weevils observed. To conduct a posteriori comparisons among preserves in each year, we used $2 \times 2$ contingency table analyses, adjusting significance thresholds for multiple comparisons.

\section{Variation in weevil and plant phenologies}

To compare magnitudes of year-to-year variation in $R$. conicus and C. canescens phenologies, we calculated coefficients of variation across years for proportion of $R$. conicus adults observed and proportion of $C$. canescens flower heads initiated by late May for each site with intensive count data in at least 3 years (Arapaho: RBO and West Foothills (3 years); Niobrara: Inner and Outer Salzman (4 years). Because levels of floral herbivory can vary greatly over even small distances (Rodriguez et al. 1994; Traveset 1995), we also compared magnitudes of spatial variation in $R$. conicus and C. canescens phenologies by calculating coefficients of variation across sites for proportions of $R$. conicus adults observed and C. $\mathrm{ca}$ nescens flower heads initiated by late May. In each year, the sample included two Arapaho sites and two Niobrara sites. To evaluate whether variation in weevil phenology or variation in thistle phenology was primarily responsible for generating variation in synchrony of their populations, we examined Pearson product moment correlations of both weevil and plant phenologies with the degree $R$. conicus preceded $C$. canescens.

We examined climate effects on variation in C. canescens reproductive phenology, 1990-2001, using multiple regression. Seasonal growing degree days and precipitation (spring: April-June, summer: July-September, autumn: October-December, winter: January-March) as well as days until last spring freeze and days until last spring hard freeze $\left(<3.9^{\circ} \mathrm{C}\right)$ were calculated from daily climate data and used as explanatory variables. We standardized climate variables for each preserve by subtracting the mean of the variable and dividing by its standard deviation. To remove effects of variation in sampling date on our measures of plant phenology we used residuals from the regression of arcsine-transformed proportion of heads initiated by May on sampling date as our dependent variable in multiple regression models. We evaluated climate models according to over-all significance, mean square error, and inclusion of non-significant explanatory variables.

\section{Effects of phenological synchrony on egg loads}

To evaluate the effect of variation in phenological synchrony of $R$. conicus and $C$. canescens populations on variation in $R$. conicus egg loads on $C$. canescens among sites and years, we regressed natural log-transformed mean egg cases per flower head on the degree $R$. conicus preceded $C$. canescens, using simple, linear regression. With each site in each year, 1997-2000, as a separate unit of observation (Platte thistle is monocarpic, precluding re-sampling between years), we had 21 combinations of sites and years.

To evaluate the hypothesis that the magnitude of asynchrony, but not the identity of the species that was earlier ( $R$. conicus or $C$. canescens), determined egg load (Louda 1998), we regressed natural log-transformed mean egg cases per flower head on the absolute value of the difference between the proportion of weevils observed and the mean proportion of $C$. canescens flower heads initiated, by late May. We refer to this absolute value as the "magnitude of asynchrony." 


\section{Results}

Variation in $R$. conicus egg loads

We found large variation among years and preserves in $R$. conicus egg load on C. canescens. At Niobrara in the year of highest use (1998), the mean number of eggs per flower head per plant (mean=3.24) was 22 times greater than egg load in the year of lowest use (2001, mean $=$ 0.15), $\left(x^{2}=33.65, d f=6, P<0.001\right)$. At Arapaho, in the year of highest use (2001), on average 3.23 egg cases were observed per flower head whereas in 1996 we observed no egg cases $\left(\chi^{2}=38.45, d f=6, P<0.001\right)$. Mean egg load averaged across years at Arapaho Prairie (mean $=2.44$ ) was $32.9 \%$ greater than at the Niobrara Preserve $\left(\right.$ mean $\left.=1.84 ; \chi^{2}=7.65, d f=1, P=0.006\right)$.
Variation in insect and plant phenology

For the 4 years (1997-2000) when we counted $R$. conicus adults twice weekly, we found a significant year $\times$ preserve interaction effect on weevil phenology $\left(\chi^{2}=54.69\right.$, $d f=2, P<0.001$; Figure 1, A \& B). A significantly higher proportion of $R$. conicus adults had appeared by late May at Arapaho than at Niobrara in 1998 and 1999. Weevil phenology did not differ significantly among preserves in 1997 or 2000. For the 12 years (1990-2001) when we sampled C. canescens plants, we also found a significant year $\times$ preserve interaction effect on $C$. canescens reproductive phenology [interaction: $F_{(1,393)}=6.94, P=0.001$ ]. In 1991 and 1994, a significantly higher proportion of flower heads produced during the season were initiated by late May at Arapaho than at Niobrara. Platte thistle phenology did not differ between preserves in any other year (Figure 1, C \& D).
Figure 1. Rhinocyllus conicus adult phenology, Cirsium canescens phenology, and phenological synchrony of $R$. conicus with $C$. canescens flower heads at Niobrara Valley Preserve (A, C, E) and at Arapaho Prairie Preserve (B, D, F) 1997-2000: A \& B.) within-season temporal distributions of $R$. conicus adults, showing running means of the number of $R$. conicus adults standardized per 20 thistle plants per preserve; C \& D.) mean (SD) percent of the seasonal total $C$. canescens flower heads per plant initiated by late May; E \& F.) degree $R$. conicus preceded $C$. canescens (\% R. conicus adults observed-\% C. canescens heads initiated, by late May); larger absolute values indicate greater asynchrony than smaller absolute values. In C-E, years are ranked by earliest to latest $R$. conicus phenology. For each preserve, $a=$ year of earliest (fastest development) $R$. conicus phenology, while $d=$ year of latest (slowest development) $R$. conicus phenology.
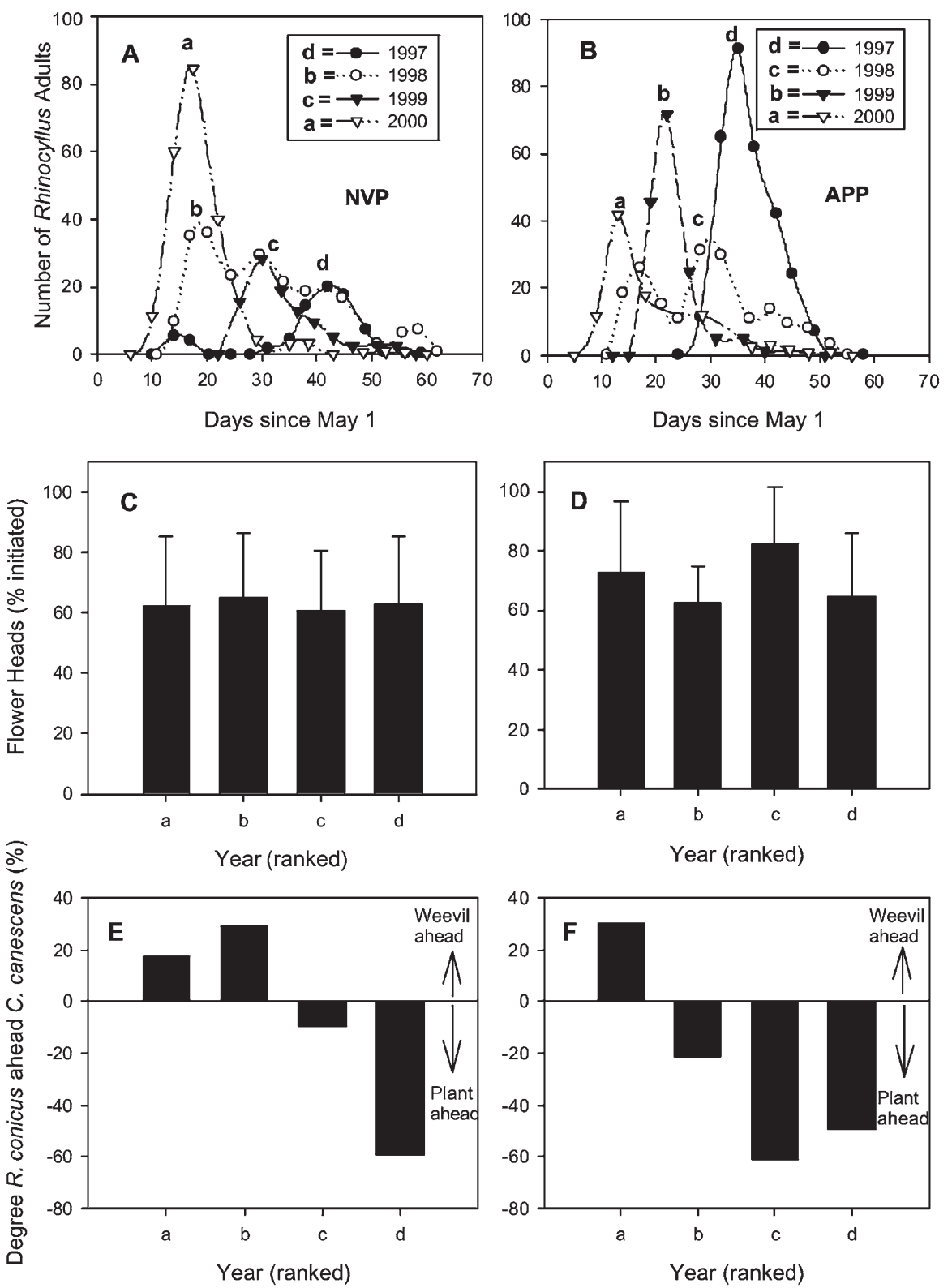
Table 3. Coefficients of variation for temporal variation in phenologies of adult activity of Rhinocyllus conicus populations and flower head development of Cirsium canescens populations. Variation among years for individual sites

\begin{tabular}{llcl}
\hline Site & Preserve & $\begin{array}{l}\text { Coefficient of variation, } \\
\text { R. conicus phenology }\end{array}$ & $\begin{array}{l}\text { Coefficient of variation, } \\
\text { C. canescens phenology }\end{array}$ \\
\hline Roses Blowout & Arapaho & 187.58 & 17.26 \\
West Foothills & Arapaho & 15.21 & 15.42 \\
Inner Salzman & Niobrara & 54.68 & 13.67 \\
Outer Salzman & Niobrara & 149.07 & 11.29 \\
\hline
\end{tabular}

The magnitudes of temporal and spatial variation in $R$. conicus phenology consistently exceeded those in $C$. canescens phenology between 1997 and 2000. At RBO (at Arapaho) and Inner and Outer Salzman (at Niobrara), coefficients of variation for year-to-year variation in $R$. conicus phenology were at least 4.0 times as great as coefficients of year-to-year variation in $C$. canescens phenology (Table 3). For West Foothills (at Arapaho), coefficients of variation for year-to-year variation in weevil and plant phenologies were equal. In each year, variation among sites in $R$. conicus phenology was greater than variation in C. canescens phenology (Table 4). Coefficients of variation for spatial variation in $R$. conicus phenology were at least 10.0 times the coefficients of variation for spatial variation in C. canescens phenology. The degree $R$. conicus preceded C. canescens was significantly correlated with $R$. conicus phenology $(r=0.979$, $P<0.0001)$, whereas it was not correlated with $C$. canescens phenology $(r=-0.288, P=0.208)$.

None of the climate variables that we examined significantly explained variation in reproductive phenology of $C$. canescens populations. Our "best" regression model $\left(R^{2}=0.258, P=0.0735\right)$ included days to last spring hard freeze $(P=0.0955)$ and spring precipitation $(P=0.1345)$. Later hard freezes and lower spring precipitation were associated with lower proportions of flower heads initiated by late May.

Synchrony and oviposition intensity

Relative phenologies of $R$. conicus and C. canescens populations affected $R$. conicus use of $C$. canescens. The natural log-transformed number of egg cases per flower head per plant was significantly, and positively related to the degree $R$. conicus preceded $C$. canescens $\left[F_{(1,19)}=7.02, P=0.016, R^{2}=0.269\right]$. However, the magnitude of asynchrony, which ignores which species (weevil or plant) was earlier, was more effective in explaining temporal and spatial variation in $R$. conicus egg load on $C$. canescens $\left[F_{(1,19)}=17.21\right.$, $\left.P<0.001, R^{2}=0.472\right]$. Egg loads were higher in years and sites where phenologies of $R$. conicus and C. canescens populations were more synchronized (Figure 2). The fit of a quadratic model for the relationship between egg load and the degree $R$. conicus preceded $C$. canescens $\left[F_{(1,19)}=17.31, P<0.001, R^{2}=0.477\right]$ was identical to the fit with magnitude of asynchrony as the explanatory variable (above).
Table 4. Coefficients of variation for spatial variation in phenologies of adult activity of $R$. conicus populations and flower head development of $C$. canescens populations. Variation among sites for individual years

\begin{tabular}{llc}
\hline Year & $\begin{array}{l}\text { Coefficient of variation, } \\
\text { R. conicus phenology }\end{array}$ & $\begin{array}{l}\text { Coefficient of variation, } \\
\text { C. canescens phenology }\end{array}$ \\
\hline 1997 & 214.08 & 12.18 \\
1998 & 123.08 & 11.83 \\
1999 & 117.25 & 7.76 \\
2000 & 78.05 & 6.36 \\
\hline
\end{tabular}

\section{Discussion}

Phenological synchrony and interaction strength

Our results show that floral herbivory by $R$. conicus, an exotic biocontrol weevil, on populations of Platte thistle ( $C$. canescens), a native North American adopted host plant, varied significantly among sites and years. In general, the mechanisms that produce variation in rates of herbivory among host plant populations and among years in individual host plant populations are poorly understood. We found that temporal and spatial variation in the degree of phenological synchrony of $R$. conicus adult activity and C. canescens floral development strongly predicted variation in levels of herbivory between plant populations and years. Use of $C$. canescens flower heads by $R$. conicus decreased as the magnitude of asynchrony between weevil and plant populations increased. The identity of the species (weevil or plant) that was earlier was less important than the degree of synchrony.

Variation in $R$. conicus adult phenology was most important in determining degree of synchrony of herbivore and plant populations. Phenology of C. canescens floral development was much less variable in space and time than was $R$. conicus phenology. Even in the continental climate of the Sand Hills, variation in temperature and precipitation did not strongly influence timing of $C$. canescens reproduction. The insensitivity of $C$. canescens reproductive phenology to climatic variation contrasts with our finding that $R$. conicus phenology is strongly influenced by winter and spring temperature and spring precipitation (Russell and Louda, submitted for publication). Large variation in $R$. conicus phenology in the new environment may reflect either exposure to novel, harsher and more variable environmental conditions or availability of alternative resources (Russell and Louda, submitted for publication). 

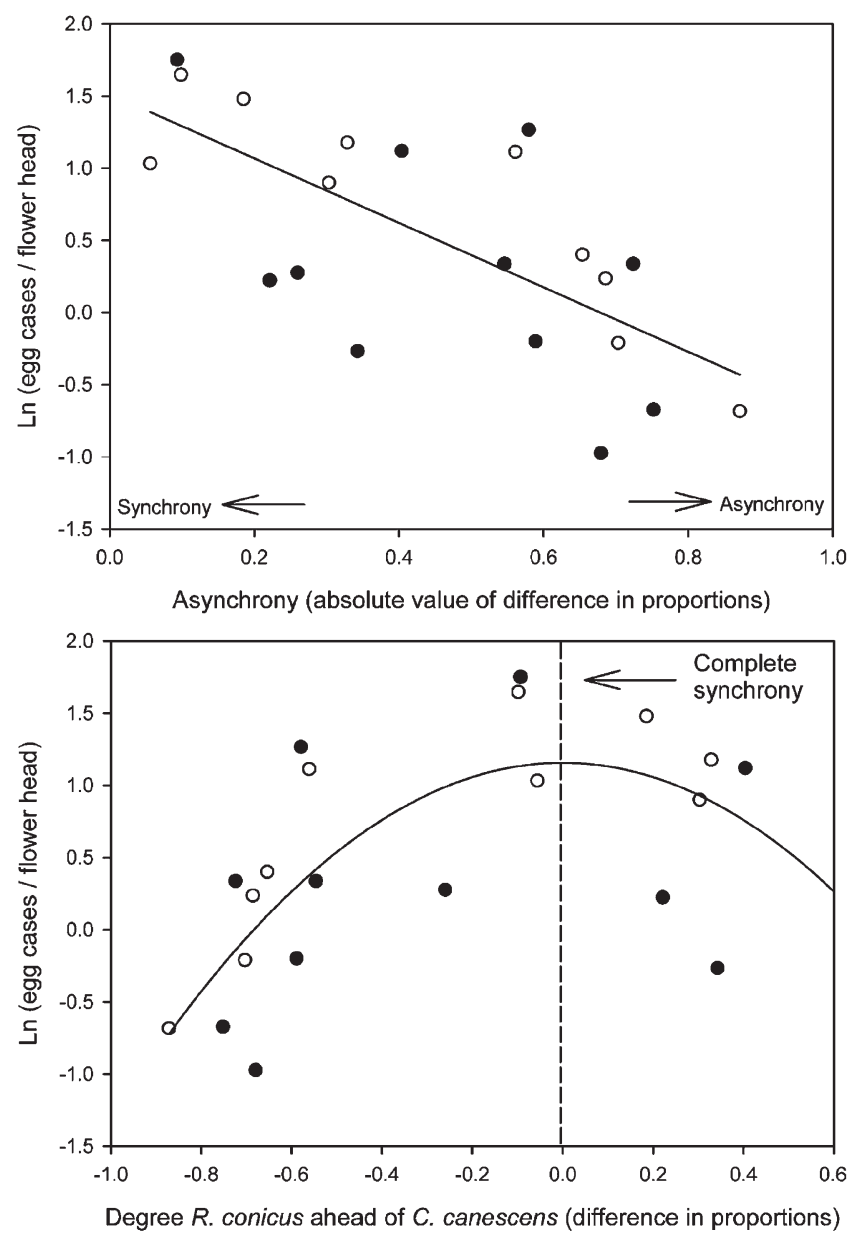

Figure 2. A.) R. conicus oviposition on C. canescens flower heads per plant as a function of the magnitude of asynchrony of phenology of the R. conicus and C. canescens populations. Magnitude of asynchrony is quantified as the absolute value of the difference between the proportion of $R$. conicus observed-the proportion of $C$. canescens heads initiated by late May. Larger absolute values indicate greater asynchrony than smaller absolute values. B.) Oviposition on C. canescens as a function of the degree that $R$. conicus preceded $C$. canescens. Positive values indicate $R$. conicus earlier than C. canescens. Negative values indicate $R$. conicus later than $C$. canescens. Solid circles represent Niobrara sites, and open circles represent Arapaho sites. In both panels, site means for number of egg cases per flower head per individual plant ranged from 5.76 egg cases/head [Mahoney site (NVP) in 1998] to 0.38 egg cases/head [Inner Salzman site (NVP) in 1999].

Large variation in rates of predispersal seed losses to floral herbivory is common among host plant populations (Jordano et al. 1990; Leimu et al. 2002) and among years (De Steven 1981; Evans et al. 1989). Such spatial and temporal variation in the intensity of herbivory can be critically important for dynamics of plant populations and communities, because it can determine landscape distributions and population sizes of host plants (Louda 1982, 1983; Rand 2002), especially when floral and predispersal seed herbivores severely limit recruitment (Louda and Potvin 1995a; Maron et al. 2002). Variation in herbivore population sizes or in the amount of plant resources available to flower-feeding insects is often hypothesized to explain differences in levels of damage among populations and years (De Steven 1981; Leimu et al. 2002). Qualitative comparisons of phenologies of some floral herbivores and their host plants have suggested that low levels of herbivory in some plant populations may coincide with large mismatches in the timing of insect activity and plant floral development (Evans et al. 1989; Jordano et al. 1990). However, prior to this study, we found only one quantitative test of the hypothesis that intraseasonal variation in the degree of phenological synchrony between inflorescence-feeding insect populations and their host plant populations drives variation in interaction strength (Rodriguez et al. 1994). Further tests of this seasonal phenological synchrony hypothesis for floral herbivore impact on interaction strength and plant population parameters are merited.

\section{Measures of seasonal synchrony of interacting populations}

Among the 18 studies we found that quantified within season phenological synchrony of consumer and resource populations, we distinguished three categories for the measures of synchrony that were used (Table 2). Seasonal phenological synchrony has been quantified as a comparison of: (1) number of days elapsed between the date of first appearance, median appearance or modal abundance of the consumer and resource populations; (2) thermal units accumulated between the date of first (or median) appearance or modal abundance of the consumer versus the resource population; and, (3) difference between the proportion of the consumer population observed by a set date and the proportion of the resource population observed by the same date. Comparison of days elapsed to first (or median) appearance or modal abundance for both populations (category 1) was overwhelmingly the most common measure of seasonal phenological synchrony, used in $72 \%$ of the 18 studies.

Quantification of phenological synchrony as calendar or developmental time elapsed-between first appearances, median appearances or modal abundances of consumer and resource populations-allows evaluation of whether the phenological time difference between populations is large enough to affect either consumer or resource individuals. For example, if the rate of change in leaf quality after budbreak is known, measuring herbivore-plant phenological synchrony in days elapsed between first appearances permits assessment of whether the first leaves to expand will be unpalatable when folivores appear. This measure of phenological synchrony, however, provides little information about the frequency distributions of phenologies among individuals in consumer and resource populations. Skewness and kurtosis of these distributions will strongly influence the proportion of each population affected by asynchrony and, hence, population growth. Comparing dates of modal 
abundances, rather than dates of first appearances, should improve prediction of effects on consumer and resource population dynamics because distribution modes likely represent the phenologies of larger proportions of individuals in the consumer and resource populations.

Measures of phenological synchrony that compare proportions of consumer and resource populations observed by a predetermined date indicate the proportion of individuals in a population that could be affected by any asynchrony. Such measures, however, often provide insufficient information to determine whether the temporal gap between consumers and resources is large enough to impact performance of asynchronous individuals. A measure of phenological synchrony that compares proportions of consumers and resources observed by a predetermined date, using a date based on the length of the phenological window during which resource individuals are vulnerable to consumers, though, could provide a robust predictor of the effect of variation in seasonal phenological synchrony on consumer and resource population dynamics.

Our measure of phenological synchrony for R. conicus and $C$. canescens populations, which was the proportion of the adult weevil population observed by late May minus the proportion of flower heads in the $C$. canescens population initiated by late May, is an example of the third category of measures of phenological synchrony above. Because our goal was to explain variation in herbivory among host plant populations, we chose a measure of phenological synchrony that we expected would closely reflect variation in the proportion of host plant individuals and their floral resources that were vulnerable to herbivory. The late May sampling date, which is related to the phenological window of weevil activity and individual flower head vulnerability in our system, was used to quantify phenological synchrony of $R$. conicus and C. canescens populations; our previous data indicated that late May was, on average, in the middle of the 3-week interval during which $R$. conicus oviposition on $C$. canescens was highest and flower head initiation was peaking. Therefore, we expected that the degree of synchrony in late May would be critical to determining weevil damage inflicted on Platte thistle populations.

Measures used to quantify reproductive synchrony of populations of masting plant species across years might be adapted to provide an additional measure of within-season synchrony of interacting populations. Reproductive synchrony of masting plant populations is usually quantified as the correlation coefficient for number of seeds produced by two populations over multiple years (Elkinton et al. 1996; Schnurr et al. 2002). Large, positive correlation coefficients indicate populations are synchronized in seed production, i.e., they mast in the same years and forego reproduction in the same years. Within a growing season, synchrony of consumer and resource populations might be quantified as the correlation coefficient for the number of consumer and re- source individuals observed by time, i.e., each week or each month. Correlation coefficients of joint abundances of consumer and resource densities obtained for different populations could be used as explanatory variables in regression analyses to evaluate whether the degree of consumer-resource phenological synchrony affects reproduction or size of consumer and resource populations. A quantitative comparison of the predictive abilities of different measures of phenological synchrony of consumer and resource populations has yet to be done, but would be a very useful next step.

\section{Conclusion}

Phenological mismatch between consumer and resource populations is increasingly recognized as a potentially important dimension of the intensity of interactions between consumer and resource species, one that is vulnerable to global climatic change. However, quantitative evidence on the effect of such variation on the properties of resource populations is very limited. We found that variation in seasonal phenology of an exotic, invasive insect floral herbivore affected the phenological synchrony of its interaction with an adopted native North American host plant. Further, the degree of phenological synchrony of populations strongly influenced the magnitude of impact of the insect on the host plant. Degree of synchrony was important here, not which species was first. Such synchrony is likely to be important in determining outcomes and strengths of consumer-resource interactions more generally as well. Our findings suggest that prediction of the effects of invasive insect herbivores on indigenous plant populations will be improved by quantifying the synchrony and variation in insect and plant phenologies.

\section{Acknowledgments}

We thank the many students, colleagues, friends, and family members who contributed to the field data collection and discussions of thistle-insect interactions since 1990, as well as C. W. O'Brien for weevil identification and S. Kachman and A. M. Parkhurst for statistical advice. We are very grateful also to colleagues who aided our search for relevant phenological studies: A. K. Brody, V. K. Brown, D. E. Bunker, A. Buse, N. Cappucino, W. P. Carson, M. J. Crawley, R. F. Denno, E. W. Evans, S. N. Handel, D. W. Inouye, R. Karban, R. J. Marquis, P. A. Morrow, R. B. Root, S. Y. Strauss and A. VanVliet. The staffs of Cedar Point Biological Station and the staffs of the Niobrara Valley Preserve of The Nature Conservancy and Cedar Point Biological Station have provided continuing encouragement and valuable field support. Partial support for the long-term data collection on thistle-insect interactions was provided by grants from: University of Nebraska Research Council, Rodney Johnson and Katherine Ordway Stewardship Endowments of The Nature Conservancy, The National Science Foundation (DEB9221065, DEB9616210), and the USDA National Research Initiative (2001-35320-09882). 


\section{References}

Alonso C, Herrera CM (2000) Seasonal variation in leaf characteristics and food selection by larval noctuids on an evergreen Mediterranean shrub. Acta Oecol 21:257-265

Angulo-Sandoval P, Aide TM (2000) Leaf phenology and leaf damage on saplings in the Luquillo Experimental Forest, Puerto Rico. Biotropica 32:415-422

Augspurger CK (1981) Reproductive synchrony of a tropical shrub: experimental studies on effects of pollinators and seed predators on Hybanthus prunifolius (Violaceae). Ecology 62:775-788

Bertin RI (1982) The Ruby-throated Hummingbird and its major food plants: ranges, flowering phenology, and migration. Can J Zool 60:210-219

Buse A, Good JEG (1996) Synchronization of larval emergence in winter moth (Operophtera brumata L.) and budburst in pedunculate oak (Quercus robur L.) under simulated climate change. Ecol Entomol 21:335-343

Buse A, Dury SJ, Woodburn RJ, Perrins CM, Good JEG (1999) Effects of elevated temperature on multi-species interactions: the case of Pedunculate Oak, Winter Moth and Tits. Funct Ecol 13:74-82

Cappuccino N, Kareiva P (1985) Coping with a capricious environment: a population study of a rare pierid butterfly. Ecology 66:152-161

Crawley MJ, Akhteruzzaman M (1988) Individual variation in the phenology of oak trees and its consequences for herbivorous insects. Funct Ecol 2:409-415

De Steven D (1981) Abundance and survival of a seed-infesting weevil, Pseudanthonomus hamamelidis (Coleoptera: Curculionidae), on its variable fruiting host plant, witch-hazel (Hamamelis virginiana). Ecol Entomol 6:387-396

Dewar RC, Watt AD (1992) Predicted changes in the synchrony of larval emergence and budburst under climatic warming. Oecologia 89:557-559

Elkinton JS, Healy WM, Buonaccorsi JP, Boettner GH, Hazzard AM, Smith HR (1996) Interactions between gypsy moths, white footed mice and acorns. Ecology 77:2332-2342

Eriksson O (1995) Asynchronous flowering reduces seed predation in the perennial forest herb Actaea spicata. Acta Oecol 16:195-203

Evans EW, Smith CC, Gendron RP (1989) Timing of reproduction in a prairie legume: seasonal impacts of insects consuming flowers and seeds. Oecologia 78:220-230

Great Plains Flora Association (1986) Flora of the Great Plains. University Press of Kansas, Lawrence, Kan.

Herrera CM, Jordano P, Guitian J, Traveset A (1998) Annual variability in seed production by woody plants and the masting concept: reassessment of principles and relationship to pollination and seed dispersal. Am Nat 152:576-594

Hill JK, Hodkinson ID (1992) Effects of temperature on phenological synchrony and altitudinal distribution of jumping plant lice (Hemiptera: Psylloidea) on dwarf willow (Salix lapponum) in Norway. Ecol Entomol 20:237-244

Hodkinson ID (1997) Progressive restriction of host plant exploitation along a climatic gradient: the willow psyllid $\mathrm{Ca}-$ copsylla groenlandica in Greenland. Ecol Entomol 22:47-54

Hodkinson ID, Bird JM, Hill JK, Baxter P (2001) Host plant growth characteristics as determinants of abundance and phenology in jumping plant-lice on downy willow. Ecol Entomol 26:371-387
Hunter AF, Elkinton J (2000) Effects of synchrony with host plant on populations of a spring-feeding Lepidopteran. Ecology 81:1248-1261

Hunter MD (1992) A variable insect-plant interaction: the relationship between tree budburst phenology and population levels of insect herbivores among trees. Ecol Entomol 16:91-95

Inouye DW, Barr B, Armitage KB, Inouye BD (2000) Climate change is affecting altitudinal migrants and hibernating species. Proc Natl Acad Sci 97:1630-1633

Jordano D, Fernandez Haeger J, Rodriguez J (1990) The effect of seed predation by Tomares ballus (Lepidoptera: Lycaenidae) on Astragalus lusitanicus (Fabaceae): determinants of differences among patches. Oikos 57:250-256

Kaitaniemi P, Ruohomaki K, Haukioja E (1997) Consequences of defoliation on phenological interaction between Epirrita autumnata and its host plant, Mountain Birch. Funct Ecol 11:199-208

Kennedy AA, McCullough DG (2002) Phenology of the Larger European Pine Shoot Beetle Tomicus piniperda (L.) (Coleoptera: Scolytidae) in relation to native bark beetles and natural enemies in pine stands. Environ Entomol 31:261-272

Kerslake JE, Hartley SE (1997) Phenology of winter moth feeding on common heather: effects of source population and experimental manipulation of hatch dates. J Anim Ecol 66:375-385

Lamp WO (1980) Predispersal seed predation of the Platte thistle and its effect on seed production. PhD thesis. University of Nebraska, Lincoln, Neb., p 173

Lawrence RK, Mattson WJ, Haack RA (1997) White spruce and the spruce budworm: defining the phenological window of susceptibiltiy. Can Entomol 129:291-318

Leimu R, Syrjanen K, Ehrlen J, Lehtila KP (2002) Pre-dispersal seed predation in Primula veris: among-population variation in damage intensity and selection on flower number. Oecologia 133:510-516

Louda SM (1982) Distribution ecology: variation in plant recruitment over a gradient in relation to insect seed predation. Ecol Monogr 52:25-41

Louda SM (1983) Seed predation and seedling mortality in the recruitment of a shrub, Haplopappus venetus (Asteraceae), along a climatic gradient. Ecology 64:511-521

Louda SM (1998) Population growth of Rhinocyllus conicus (Coleoptera: Curculionidae) on two species of native thistles in prairie. Environ Entomol 27:834-841

Louda SM (1999) Negative ecological effects of the musk thistle biocontrol agent, Rhinocyllus conicus Fröl. In: Follet PA, Duan JJ (eds) Nontarget effects of biological control. Kluwer, Boston, Mass., pp 215-243

Louda SM, Arnett AE (2000) Predicting non-target ecological effects of biological control agents: evidence from Rhinocyllus conicus. In: Spencer NR (ed) Proceedings of the 10th International Symposium on the Biological Control of Weeds. Montana State University, Bozeman, Mont., pp 551-567

Louda SM, Potvin MA (1995a) Effect of inflorescence-feeding insects in the demography and lifetime fitness of a native plant. Ecology 76:229-245

Louda SM, Potvin MA (1995b) Effect of inflorescence-feeding insects on the demography and lifetime fitness of a native plant. Ecology 76:229-245

Louda SM, Kendall D, Connor J, Simberloff D (1997) Ecological effects of an insect introduced for the biological control of weeds. Science 277:1088-1090 
Maron JL, Combs JK, Louda SM (2002) Insect herbivory on thistles: congruent interaction strengths in coastal vs. continental dunes. Ecology 83:3382-3392

Martel J, Hanhimaki S, Kause A, Haukioja E (2001) Diversity of birch sawfly responses to seasonally atypical diets. Entomol Exp Appl 100:301-309

Mopper S, Simberloff D (1995) Differential herbivory in an oak population: the role of plant phenology and insect performance. Ecology 76:1233-1241

Ollerton J, Lack A (1998) Relationships between flowering phenology, plant size and reproductive success in Lotus corniculatus (Fabaceae). Plant Ecol 139:35-47

Peterson MA (1997) Host plant phenology and butterfly dispersal: causes and consequences of uphill movement. Ecology 78:167-180

Pilson D (2000) Herbivory and natural selection on flowering phenology in wild sunflower, Helianthus annuus. Oecologia 122:72-82

Quiring DT, McKinnon ML (1999) Why does early-season herbivory affect subsequent budburst? Ecology 80:1724-1735

Rand TA (2002) Variation in insect herbivory across a salt marsh tidal gradient influences plant survival and distribution. Oecologia 132:549-558

Rathcke B, Lacey EP (1985) Phenological patterns of terrestrial plants. Annu Rev Ecol Syst 16:179-214

Rodriguez J, Jordano D, Fernandez Haeger J (1994) Spatial heterogeneity in a butterfly-host plant interaction. J Anim Ecol 63:31-38

Schnurr JL, Ostfeld RS, Canham CD (2002) Direct and indirect effects of masting on rodent populations and tree seed survival. Oikos 96:402-410

Sokal RR, Rohlf FJ (1995) Biometry, 3rd edn. Freeman, New York

Stenseth NC, Mysterud A (2002) Climate, changing phenology, and other life history traits: nonlinearity and match-mismatch to the environment. Proc Natl Acad Sci 99:13379-13381
Surles WW, Kok LT (1977) Ovipositional preference and synchronization of Rhinocyllus conicus with Carduus nutans and C. acanthoides. Environ Entomol 6:222-224

Thireau JC, Regniere J (1995) Development, reproduction, voltinism and host synchrony of Meteorus trachynotus with its host Choristoneura fumiferana and C. rosaceana. Entomol Exp Appl 76:67-82

Tikkanen O, Carr TG, Roininen H (1999) Factors influencing the distribution of a generalist spring-feeding moth, $\mathrm{Op}$ erophtera brumata (Lepidoptera: Geometridae), on host plants. Environ Entomol 28:461-469

Traveset A (1995) Spatio-temporal variation in pre-dispersal reproductive losses of a Mediterranean shrub, Euphorbia dendroides L. Oecologia 103:118-126

Van Noordwijk AJ, McCleery RH, Perrins CM (1995) Selection for the timing of Great Tit breeding in relations to caterpillar growth and temperature. J Anim Ecol 64:451-458

Visser ME, Holleman LJM (2001) Warmer springs disrupt the synchrony of oak and winter moth phenology. Proc R Soc Lond B 268:289-294

Volney WJA, Cerezke HF (1992) The phenology of white spruce and the spruce budworm in northern Alberta. Can J For Res 22:198-205

Watt AD, McFarlane AM (1991) Winter moth on Sitka spruce: synchrony of egg hatch and budburst and its effect on larval survival. Ecol Entomol 16:387-390

Zwölfer H, Harris P (1984) Biology and host specificity of Rhinocyllus conicus (Froel.) (Col., Curculionidae), a successful agent for biocontrol of the thistle, Carduus nutans L. Z Angew Entomol 97:36-62 